\title{
The Immigrant and America: Assimilation of a German Family Part II
}

C. Carnahan Goetsch

Part I of this study (published in the Summer 1973 issue of the Annals, Vol. 42, No. I) dealt with the adjustment to America of the Marx Goettsch family during the latter part of the nineteenth century. They settled in Davenport, lowa where Mr. Goettsch bought property and built a house that functioned as shoemaking shop and home for his family. Henry, eldest of the six children, aspired to a college education at a time when such pursuits were not commonly followed by sons of the working class. Part II details the experiences of Henry's brothers as they sought advanced education and subsequently embarked on professional careers.-Ed.

FOR ALL THE SUCCESS WHICH HENRY HAD in leaving home for college, Charles, the second eldest boy, still encountered some resistance from his father. A German tavern owner in Davenport named Peter Jacobson had a large family of sons but did not trust any of them. In the days before cash registers, it was an easy temptation for a bartender to dip into the till, and that was just what Jacobson's sons were doing in his saloon. So one night Peter talked to Marx and told him he would give the job of saloonkeeper to whichever one of his sons Marx believed to be honest and available. Marx was delighted with the offer and promised that Charles, who was about to graduate from high school, would accept. When he came home and told Charles about the position, Charles politely refused, saying that he had already decided to go to the University of lowa. When his father asked him why he wanted to go to college, Charles replied that he would study to become a Professor of German and Linguistics. This was too much for Marx, 


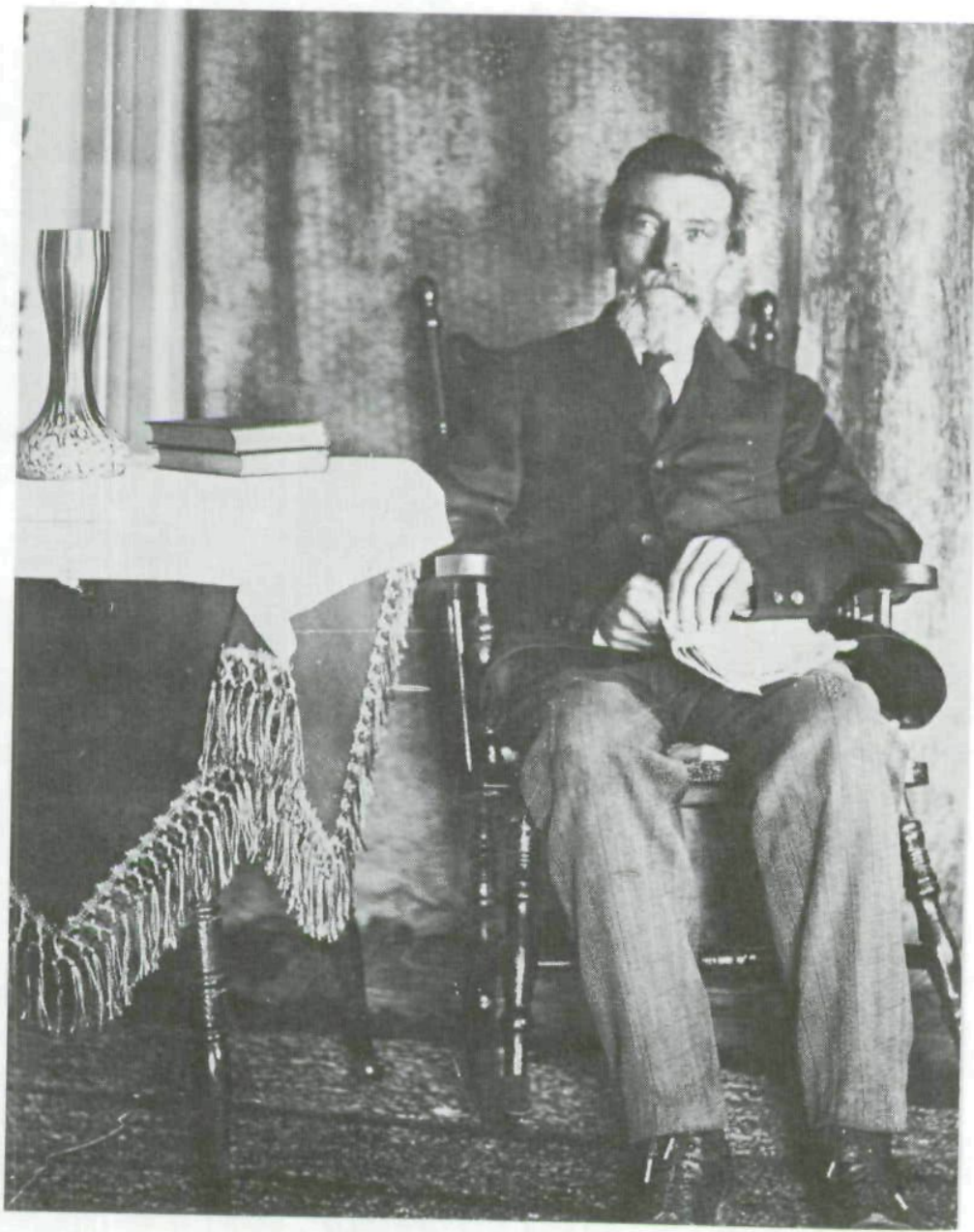

Marx Goettsch at age 45

Courtesy of Author

who could not comprehend traveling all the way to Des Moines to learn something Charles already knew, when there was a lucrative job open to him in Davenport. The resulting argument was finally settled by Anna when she flatly refused to let any son of hers earn his living in a saloon, regardless of whether he wanted to go to college or not.

By the time Julius left for college a year later, Marx had more or 
less given up resisting. Even though Henry's education had not yet started to pay for itself, Marx resigned himself and waited to see how everything would turn out. He allowed that if his sons were so stubborn and determined about college, there must be some redeeming value to it.

After his freshmen year at the University of lowa, Julius found himself interested in engineering, and consequently decided to transfer to either Cornell or MIT. He eventually chose Cornell since he believed it to have the better department. He took a train to Ithaca, New York at the start of his sophomore year, not to return home until two years later, since he had to work summers for tuition money and did not possess the necessary cash for the train fare. When he finally did return to Davenport, the first thing his mother asked him was not about school but rather "How is the beer in Ithaca?" Julius replied that he really could not say since he did not have enough money to buy much of it. At this, Anna turned white and exclaimed, "My boy! My boy! Look what they've done to my boy! He's sick and hungry and doesn't get enough to drink!" whereupon she ran into the kitchen and brought out a bucket of beer and a steaming dinner of sausage and sauerkraut. She was horrified that any son of hers was living in a strange and alien place where it was difficult to get such a basic staple of life as beer.

The University of Chicago actively recruited students from the Davenport area and from many other Middle Western cities and towns. The University was from its inception (1892) publicized as a new institution without traditions, but which nevertheless possessed energy and vision equal to that of any major university. Backed by the money of John D. Rockefeller and headed by a vigorous president, William Rainey Harper, the University attracted a high calibre of professors from all fields. Along with an energetic and prestigious faculty and graduate program went a policy of recruiting the best students in the Middle West away from their local state universities by offering them opportunities for scholarship aid and an education equal, if not superior, to those provided by the more established and expensive colleges in the East.

Thus beginning about the time Emil was graduating from high school (1899), a drummer, as they were then called, appeared each year in Davenport and contacted the students recommended by their high school administration. The recruiter, who was pleased with Emil's grades, attitude, and ability to play the clarinet, talked to him 
about the University, and then offered him an undergraduate scholarship. Emil accepted the offer, and the drummer then asked if he knew of any other students who might be interested in the University of Chicago. Emil said that as a matter of fact, he did know of two people who might be, and then introduced him to his brothers, Charles and Arthur. Henry, Charles, Emil, and Arthur all eventually did their graduate work at Chicago, and Emil and Arthur enrolled as undergraduates after leaving high school.

Henry received his Ph.D. in Chemistry from the University of Chicago in 1906, at the age of thirty-six. He was always considered the wisest and most philosophically serene by his four younger brothers, for he would settle any arguments with his resolute good will and reason. Three of his daughters are living today, two of whom are medical doctors, Elvira and Erna, and one, Marianne, who is a Ph.D. Henry died in 1956 at the age of eighty-six.

Charles received his Ph.D. in 1906 and remained at the University of Chicago, joining the German Department as an associate professor specializing in Mittelhochdeutsch, or Middle High German, and Philology. He was married in 1911 and had one daughter, Margaret, who is living today and practicing medicine. Although Charles was at times tempted to leave the city by such offers as the chairmanship. of the German Department at the University of North Carolina at Chapel Hill, he preferred to stay in Chicago where he could enjoy the pleasures he had become accustomed to: the Chicago Symphony, golf, and beer off the beer truck at tavern prices. His book, The Phonology of the Low German Deeds in the Oldest Registry at Riga, Latvia, is a standard listing in most college library catalogues. He died in 1940 at the age of sixty-five. ${ }^{6}$

Julius graduated from Cornell in 1906 with a degree in engineering and went on to work as a consultant engineer in the city of Chicago. He was married in 1909 and bought a house in Oak Park, Illinois, a suburb of Chicago. He had two sons, Carl and John, who are now practicing medicine, and one daughter, Elizabeth, who is a retired associate editor of The Ladies Home Journal. Julius died in 1965 at the age of eighty-nine.

Emil received his B.S. degree in 1903 and his Ph.D. in Anatomy from the University of Chicago in 1906. His thesis, a comparative

${ }^{6}$ New York Times Obituary, Charles Goetsch, Ph.D. (New York, May 1, 1940), p. 23. 
study of mammalary esophagi, is still a standard anatomical text on that subject. He went on to receive his M.D. from Johns Hopkins in 1909 , training with Dr. William S. Halstead. From $1912-1915$ he was assistant surgeon at Harvard Medical School, and from 1915-1918 he was associate surgeon and associate professor at Johns Hopkins. Emil eventually became one of the pioneers of modern American surgical technique and teaching, especially in the area of the thyroid. He helped institute the method of training doctors known as the residency system, a program which is still an integral part of every young doctor's training. From 1919 to 1948 he was a surgeon in chief at Columbia Hospital, professor of surgery at the Long Island College of Medicine, and surgeon in chief of the Long Island College Hospital. He died in 1963 at the age of eighty.?

Arthur graduated from the University of Chicago in 1906 and received his M.D. in 1912 from the Rush Medical College, which is affiliated with the University of Chicago. After his early training and residency, which he spent in connection with his brother Emil, he went into practice in a partnership with Emil, beginning in 1919 and ending in 1953 when his brother retired. Their partnership was a complimentary and successful one since Emil had the dedicated objectivity of the scientist whereas Arthur was more sympathetic to the individual, personal needs of their patients. Their offices were in Brooklyn, near the Long Island College Hospital. Arthur himself retired from surgery in 1958, and is presently living in Fort Lee, New Jersey.

Although she dearly wanted to, Minnie was never allowed to attend high school. In view of her excellent record in elementary school, her principal originally suggested to her parents that she be sent through the advanced grades, but Marx and Anna left the decision to Henry, who was then 15 years old. At that time Henry held the common opinion that a woman's place was in the kitchen, church, and home, and so Minnie was apprenticed out to a tailor. She turned out to be a good seamstress, specializing in the making of vests at Muhs Brothers, a German clothier store in downtown Davenport. She worked there ten hours a day and six days a week, which was the usual routine.

But she did not neglect her education. With the help of her

${ }^{7}$ New York Times Obituary, Emil Goetsch, Ph.D., M.D. (New York, May 24, 1963), p. 31. 
brothers she read their books as they progressed through high school. She taught herself to read French, and was, as were all the Goettsch children, bilingual in German and English. Besides being well-read in various subjects she also enjoyed music, and in the course of her life acquired a fine collection of records. The Goettsch family belonged to the local Turn-Verein, where she was a leader among the women gymnasts, a member of the women's bowling team, and a good swimmer and dancer. When Marx died in 1914 and left his estate to be divided among his children, the five boys voted unaminously to give the entire inheritance to Minnie. It was often said by her brothers that she was just as smart if not smarter than they, but that her position as a female closed to her the opportunities which a higher education brought to them.

At thirty years of age Minnie married Henry Kohrs, Jr., a native of Davenport and the oldest son of the Kohrs Meat Packing Company family. The Kohrs had first started out by raising livestock in the neighboring areas of Davenport, eventually processing and distributing their own sausage, beefsteak, and other meat products. Their meat packing company was later bought out by Armour. Henry Jr. was the black sheep of his family, a kind alcoholic with a delightful personality who was wonderful with children but who was unable to profitably run any business. Although Minnie's marriage was subsequently difficult at times, she never had any regrets, for she was totally devoted to her husband and derived her chief happiness from being with him.

Ten years after their marriage, Henry Jr. and Minnie bought a small farm in Scott County, lowa just south of Davenport on the western bank of the Mississippi River. They maintained approximately 1,000 chickens, and their main product was eggs, but they also raised a few Jersey cows, alfalfa, and a vegetable garden large enough to satisfy their personal needs. Besides overseeing the running of the small farm, Minnie was an enthusiastic member of the local Grange, where she debated and won many prizes in the baking contests.

Minnie and Henry Jr. did not have any children, and so they were fond of inviting their young nieces and nephews down to visit them during the summer months. John Goettsch, the second son of Julius, remembers watching his Uncle Henry shuffle down the dirt road toward his farmhouse in a pair of knee-high farmer boots and 
wondering why he would wear such heavy boots in the middle of sweltering hot July afternoons. He later came to realize that, it being the Prohibition Era of the early twenties, his Uncle had merely been returning from a makeshift distillery up the road with a bottle of white water corn whiskey in each boot.

When Henry Jr. died in 1924, Minnie's brothers were glad to see her finally liberated from her marriage. But Minnie could never bring herself to agree. In 1925, just one year after her husband's death, she died of cancer.

The original family name of Goettsch was used by Marx and his son Henry throughout their entire lives. Emil first changed his name to Goetsch in 1909, about the time he graduated from Johns Hopkins, in the hope that it would simplify telephonic communication. Charles, Julius, and Arthur also changed their names to Goetsch around this time, and their four children have kept the spelling. Henry's daughters, Marianne, Elvira, and Erna, however, preserved the original form, as did Minnie. This has always been a sore spot for Arthur, who would prefer the family name to have a uniform spelling, but the three sisters claim that their father Henry was just as "stolz" ("proud") as his youngest brother and that it would have broken his heart if his daughters changed their name.

The five Goettsch brothers were never as fervent political believers as was their father, Marx. They were inducted into their initial political awareness by their father, so they leaned toward the Democratic Party, yet never voted slavishly along set party lines. They sympathized with Robert La Follette of Wisconsin and the progressive causes present before World War One. Julius would always vote for Norman Thomas whenever he appeared on the ballot as a protest vote. Arthur at first voted for Franklin D. Roosevelt but grew tired of him and voted against him in his last few elections.

Other men who influenced the Goettsch brothers when they were young were Carl Schurz and President William Rainey Harper of the University of Chicago. They admired Carl Schurz tremendously for the active role he played in the Federal Government and in reforming the organization and curriculum of the public school system. In Schurz they recognized the accomplishments which a German immigrant could achieve if he was honest, hardworking, and sure of his convictions. In the figure of President Harper, they recognized a man who pursued his goals with great energy, personal showmanship, and serious concern. The brothers were impressed and 
intrigued by the relationship between Schurz' and Harper's personalities and the scope and effectiveness of their achievements.

Marx died in 1914 at the age of seventy, shortly after the start of World War One. When he first heard of the Austrian Archduke's assassination, he shook his head and said, "Es gibt krieg." ("This means war."). Anna, his wife, never seemed very content after his death. She moved back and forth from Minnie's farm in lowa to Henry's house in Cincinnati, and eventually died in 1917.

By the time America declared war on Germany in 1917, a combination of age, professions, and family status exempted Henry, Charles, Julius, and Emil from armed service. Arthur, however, was young enough, unmarried, and a doctor besides, and so he fought "The Battle of the Virgin Islands" as he calls it. This involved being stationed in the Virgin Islands with a Navy Medical Group in order to treat returning wounded soldiers. He enjoyed the locale and nature of his assignment since he considered healing the wounded to be the only constructive part of the war. He recalls conversations he held with a fellow officer, an Irish-American, in which they decided one of the unfortunate aspects of war was its power to make people vilify and hate their enemy. The wave of anti-German feeling which swept the country during World War One had some effect on the Goetsch brothers, but not in any extreme or violent manner. Julius Goetsch had his name legally changed to Getch in 1917, and it was not until 1924 that he changed it back. This action was not approved of by Charles, the German philologist, who maintained that if Julius wanted to change his name he should not bastardize it but change it to his wife's name, which was Black and sounded more American anyway. Thus there was both a resistance and surrender to the anti-German feeling caused by the war, but all the brothers felt fortunate not to have been required to fight against the Germans in France.

Their German heritage influenced the Goetsch brothers in varying degrees. It was natural that Charles, a German professor, continued the tradition he had grown up in. He and his wife spoke nothing but German in their home so that their daughter, Margaret, as a young child, at first had difficulty understanding her playmates. All the brothers preserved their taste for traditional German foods and beer, and whenever together spoke Plaudeutsch freely.

Arthur, the only surviving brother, still speaks German with his housekeeper and always serves his favorite German dishes to his 
guests. He has traveled extensively in Germany and is proud of what Charles called his "sprachgefühl," or "feel for the language." His chief hobby and entertainment over the years has been listening to German music, particularly German opera. Arthur was the most zealous pro-German in the family, sympathizing with the Nazi Party during its formative years, disliking the French as did his father, and generally distrusting the English. During the years prior to World War Two, however, Arthur began to have his doubts about the Nazis. By the time his nephews Carl and John returned home from Paris after having served as captains (medical surgeons) in the U.S. Army's XLth General Hospital Group, Arthur was throughly convinced of the Nazi's infamy.

Henry commented at the beginning of World War Two that if only the German people themselves were allowed to decide their fate everything would pass over without a world war. He maintained that it was always the German leaders who got everything wrong. His opinion was no doubt influenced by the feelings of Marx, who left Germany in part because he refused to knuckle under the rule of Bismarck's government, and who empathized with the ideas of Germanic socialism imported into America by many nineteenth century immigrants. This incipient political radicalism, evident to a slight degree among the brothers, was most forcefully expressed by Marianne, Henry's eldest daughter, who has been an ardent anarchist all her life.

Although less of a Germanophile than Charles or Arthur, Henry was definitely comfortable with his heritage. He lived in Cincinnati, where there is a large German community, and he enjoyed indulging in such customs as making white wine in his cellar. Julius did not go out of his way to observe his heritage, but he did adamantly insist that his three children be taught the German alphabet along with the English, and he later required them to learn German in school. Julius disliked wars of any sort, but when his two sons became involved in World War Two, he never said anything about Germany's or America's role which would have made them uncomfortable to be American soldiers. He seemed more interested in the economic aspect of the war.

Of all the sons, Emil was the least concerned with his German roots. He could speak German, of course, but, having originally planned to be a Classics major in college, he could also read Greek and Latin, and perhaps this identification with languages other than 
German made his ability to think and express himself in German seem less important. He was totally committed to the science of medicine and devoted to its further exploration, and he enjoyed the urban social environment of New York City where he maintained his practice and home. He never rejected his background, being fond of frequenting German restaurants with his friends and brothers and of reminiscing in Plaudeutsch, but he never defended his heritage with such reverence or enjoyed it with such gusto as did some of his brothers.

Of the five sons and one daughter of Marx and Anna Goettsch, two received M.D. degrees, three received Ph.D. degrees, and one received a degree in engineering. The daughter was not allowed to go to high school. Of Marx's seven grandchildren, five received M.D. degrees, one received a Ph.D. degree, and one received an A.B. Four brothers of the first generation had university affiliations, and all six members of the second generation with higher degrees are, or have been, affiliated with university medical schools.

The most striking feature of the second generation is the educational attainments of the women. Five of the seven grandchildren were female. Of those five, three earned M.D. degrees, one earned a Ph.D., and one earned an A.B. Marianne earned her Ph.D. and Elvira her M.D. when it was still relatively unusual for women to pursue such advanced degrees. The last time they visited their Aunt Minnie, she asked them many questions about their university experiences and told them how pleased she was that their father, Henry, had changed his views concerning the education of women. Marianne has spent her life exploring the precise properties and implications of Vitamin E, working at such institutions as the University of California at Berkeley and Columbia University. Elvira just recently published a definitive monograph on nephritis.

Carl and John, the only male grandchildren, are both practicising physicians. Carl is an obstetrician and Associate Clinical Professor of Obstetrics and Gynecology at the University of California Medical School at San Francisco. John is a urologist and Associate Professor of Surgery at the Yale University Medical School.

Slight remnants of their German heritage may be found in the grandchildren's preference for certain foods, drink, and music, but they do not share a strong, common bond of Germanic background as did the five Goettsch brothers and their sister. Marx's great-grandchildren for the most part do not speak German, have had little 
contact with their German heritage, and entirely identify themselves as Americans.

Marx Goettsch was an archetypal immigrant, a man who severed all the ties of family, friends, and homeland and journeyed across an ocean to a strange land and alien culture. For Marx, there was opportunity through immigration: opportunity for social freedom, opportunity for economic advancement, and opportunity for his children. His immigration was absolute in a time when absolute immigration was a viable possibility, an alternate choice to staying home which was eminently practical.

But for Marx's sons, this kind of immigration was not as possible and even less desirable. For the Goettsch brothers, there was opportunity through education, and in the pursuit of their education they experienced an immigration equal if not greater than that of their father's. From first generation immigrant sons in a small Middle Western city who spoke Plaudeutsch in their home, they became prominent doctors, professors, and engineers living in such sophisticated metropolitan areas as New York City, Chicago, and Cincinnati. Their immigration was not only social and economic, it was intellectual as well. When their lives are compared with the roots and experience of their father Marx, it is as if they had indeed immigrated to another world.

The influence which the physical and cultural environment of late nineteenth century America exerted on the degree and success of these immigrations cannot be underestimated. It was the vast, open potential of America's land and society which originally attracted men such as Marx and convinced them that there was indeed opportunity through immigration. It was the philosophy and practice of American public education which allowed the Goettsch brothers to attend various universities with scholarship aid and thus realize the opportunities which would have been closed to them in Germany. There was also something less tangible in the character of American life which influenced the direction that the immigration of the five brothers and their children would take. It is hinted at in the words of Arthur Goetsch:

Well, you know, money seems to be at the root of everything, because without móney you can't get anywhere-but even with money you don't necessarily end up getting somewhere either. ${ }^{8}$

${ }^{8}$ Arthur Goetsch, 'Four Hour Taped Interview' (Fort Lee, New Jersey, 1971). 
It was this concept of "getting somewhere," measured not by the accumulation of money but by one's service to other individuals through such professions as teaching, medicine, and public service, which the Goettsch brothers considered to be their ultimate goal. Such feelings have motivated many of America's leading and influential men, men who often started out as immigrants or immigrant sons and who, in the process of gaining economic security and wealth, maintained this concept of getting somewhere as their guiding ideal. Men such as President William Rainey Harper, Robert La Follette, Carl Schurz, William S. Halstead and various other doctors and teachers provided an example to the Goettsch brothers and their children that getting somewhere was a distinct possibility in America.

In a sense, there is in everyone an urge to in some way emigrate beyond the known world of one's childhood and to somehow seek freedom and self-definition beyond the established values and knowledge of one's parents. The expression or suppression of this force plays an influential role in the development of any nation's history, but most particularly in that of America's, a nation created and sustained by immigrants.

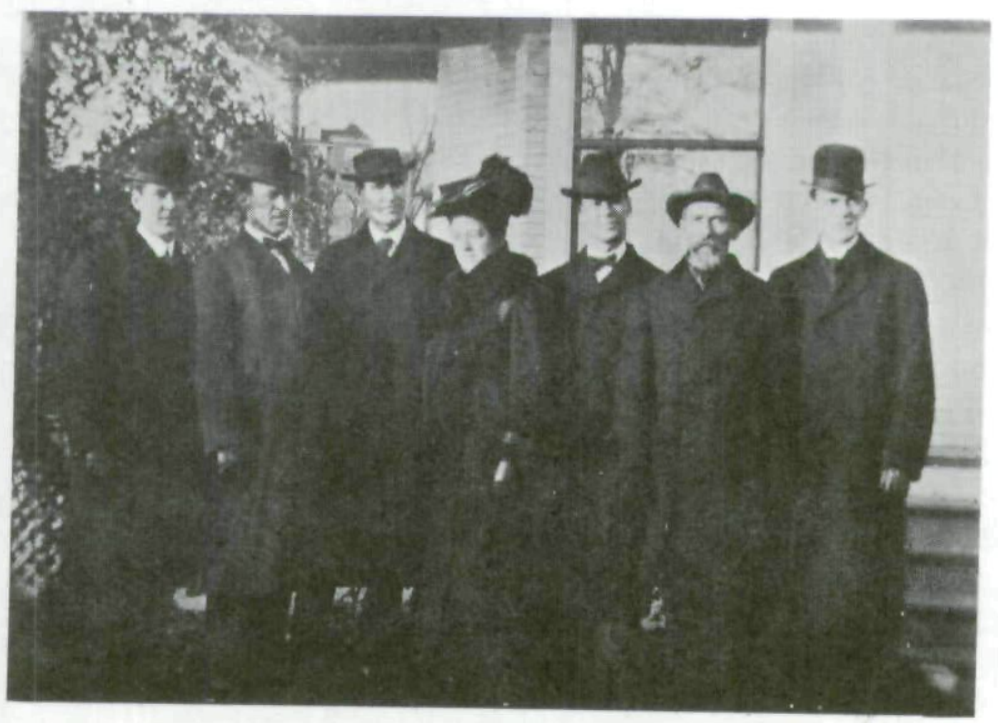

Courtesy of Author

The Goettsch family, from left to right, Emil, Charles, Arthur, Minnie, Henry, Marx and Julius. Circa 1910. 
Copyright of Annals of Iowa is the property of State of Iowa, by \& through the State Historical Society of Iowa and its content may not be copied or emailed to multiple sites or posted to a listserv without the copyright holder's express written permission. However, users may print, download, or email articles for individual use. 